\title{
Pemberian Fusarium Non-Patogen dan Trichoderma Untuk Menghambat Penyakit Busuk Pangkal Pada Bawang Putih
}

\author{
SILVIA SEPTHIANI ${ }^{1}$, DIAH OGA NUSANTARI ${ }^{1}$, DENI NASIR $^{1}$ \\ ${ }^{1}$ Program Studi Pendidikan Biologi, Fakultas Teknik Matematika dan IPA, \\ Universitas Indraprasta PGRI Jakarta \\ Jl. Nangka No. 58 C, Jagakarsa, Jakarta Selatan. 12530 \\ Email: silvia.septhiani@gmail.com
}

Received 2 February 2018; Received in revised form 13 February 2018;

Accepted 9 April 2018; Available online 27 June 2018

\begin{abstract}
The need for garlic is quite high in Indonesia, but it is not offset by the amount of production. The decrease in production is caused by one of them by a base rot. This study was aim to determine the effect of the use of antagonistic fungi in overcoming base rot in garlic. The antagonistic fungi used are Trichoderma and non-pathogenic Fusarium. This research was conducted using a Completely Randomized Design (CRD) with 3 factors each with 2 treatment levels, resulting in 8 treatment combinations. The results showed that non-pathogenic Fusarium without integrated with other fungi reduced the symptoms of rotten tubers and increased the weight of fresh and weighted tubers. The integration of pathogen and non-pathogen Fusarium, also Trichoderma can reduce the symptoms of base rot.
\end{abstract}

Keywords: garlic, non-pathogen Fusarium, Trichoderma

\section{INTISARI}

Kebutuhan bawang putih cukup tinggi di Indonesia, namun tidak diimbangi dengan banyaknya produksi. Penurunan produksi disebabkan salah satunya oleh penyakit busuk pangkal. Tujuan dari penelitian ini adalah mengetahui pengaruh dari penggunaan cendawan antagonis dalam mengatasi penyakit busuk pangkal pada bawang putih. Jamur antagonis yang digunakan adalah Trichoderma dan Jamur Fusarium non-patogen. Penelitian ini dilakukan dengan menggunakan Rancangan Acak Lengkap (RAL) dengan 3 faktor masing-masing dengan 2 taraf perlakuan, sehingga diperoleh 8 kombinasi perlakuan. Hasil penelitian menunjukkan pemberian Fusarium non-patogen tanpa diintegrasikan dengan jamur lain menurunkan gejala umbi busuk dan menaikan berat berangkasan segar dan berat umbi. Pengintegrasian Fusarium patogen, Fusarium non-patogen dan Trichoderma mampu menurunkan gejala busuk pangkal.

Kata Kunci: bawang putih, Trichoderma, Fusarium non-patogen

\section{PENDAHULUAN}

Bawang putih merupakan salah satu komoditas penting di Indonesia. Kebutuhan bawang putih di Indonesia cukup tinggi namun hal ini tidak diimbangi dengan jumlah produksi bawang putih yang ada. Data BPS menyatakan bahwa produksi bawang putih dalam negeri semakin menurun, seiring dengan menurunnya jumlah luas lahan penanaman bawang putih. Ada banyak faktor yang mempengaruhi pertumbuhan tanaman bawang putih salah satunya adalah mikroorganisme tanah yang hidup di daerah rhizosfer. Interaksi antar mikroorganisme yang beragam tersebut dapat menentukan pertumbuhan tanaman. Cendawan tanah ini memiliki fungsi yang cukup penting yaitu menjaga ketersediaan unsur karbon (C) sebagai sumber energi mikroorganisme dan juga tanaman (Subowo $d k k .$, 2015).

Fusarium oxysporum merupakan cendawan yang berpotensi sebagai patogen dengan menyebabkan penyakit busuk pangkal pada tanaman pertanian, di antaranya bawang putih, kentang, tomat dan lainnya (Rahayu $d k k ., 2015)$. Penyakit busuk pangkal yang disebabkan oleh Fusarium oxysporum f. sp. cepae merupakan salah satu pembatas produksi. Gejala penyakit busuk pangkal yang disebabkan oleh $F$. oxysporum f. sp. cepae adalah terjadinya pengeringan dan pengeritingan daun dimulai dari ujung serta pembusukan umbi atau perakaran (Choiruddin, 2010).

Fusarium non-patogen dapat digunakan sebagai agen pengendali hayati. Fusarium non-patogen banyak digunakan untuk 
mengendalikan jenis patogen di antaranya untuk menekan laju penyakit pada tanaman tomat (Kristiana $d k k ., 2015)$.

Trichoderma harzianum terbukti sebagai agensia hayati yang dapat memberikan pengaruh positif terhadap perakaran tanaman, pertumbuhan tanaman dan hasil produksi tanaman (Herlina dan Pramesti, 2004). Trichoderma mampu mengurangi kejadian patogen tular tanah pada kondisi alamiah. Beberapa faktor seperti $\mathrm{pH}$, tanah, aerasi dan sumber nutrisi merupakan faktor yang mempengaruhi perkembangan Trichoderma sp. Berdasarkan kemampuan kedua jamur antagonis ini maka perlu dikaji pengaruh penggunaan kedua jenis jamur ini dalam mengendalikan gejala busuk pangkal pada bawang putih. Tujuan dari penelitian ini adalah untuk melihat pengaruh dari penambahan Fusarium non-patogen dan Trichoderma dalam menghambat penyakit busuk pangkal pada bawang putih.

\section{METODE}

Rancangan Penelitian. Proses penelitian dilakukan di Ciangsana Bogor. Penelitian ini dilakukan dengan menggunakan metode Rancangan Acak Lengkap (RAL) dengan 3 faktor perlakuan masing-masing dengan 2 taraf perlakuan, sehingga didapatkan 8 kombinasi perlakuan. Tiap perlakuan dilakukan sebanyak 3 kali adapun kombinasi perlakuan yang di uji yaitu

FOTONO = Kontrol tanpa perlakuan

F0T0N1 = Dengan Fusarium non-patogen

F0T1N0 $=$ Dengan Trichoderma

F0T1N1 = Dengan Trichoderma, dan Fusarium non-patogen

F1T0N0 = Dengan Fusarium
F1T0N1 = Dengan Fusarium dan Fusarium non-patogen

F1T1N0 = Dengan Fusarium, dan Trichoderma

F1T1N1 = Dengan Fusarium, Trichoderma, dan Fusarium non-patogen.

Prosedur Penelitian. Tanah dicampur dengan pupuk kompos dengan perbandingan $2: 1$. Tanah yang sudah diberi pupuk kemudian dimasukan ke dalam polybag. Trichoderma dilarutkan dalam air kemudian dicampurkan pada media tanah. Tanah yang mengandung Trichoderma (T1) dan yang tidak mengandung Trichoderma (T0). Fusarium non-patogen dilarutkan dan dicampurkan pada media tanah yang sebelumnya sudah diberi Trichoderma. Tanah yang dicampur dengan Fusarium patogen diberi symbol (F1) dan yang tidak dicampur (F0). Bibit bawang putih yang sebelumnya direndam dengan Fusarium nonpatogen (N1) ditanam setiap polybag ditanam sebanyak 3 bibit bawang putih. Bibit yang tidak mengandung Fusarium patogen ditanam sebanyak 3 bibit dalam setiap polybag. Perawatan tanaman sampai masa panen. Masa panen dilakukan saat usia tanaman 120 hari.

Analisis Data. Variabel yang diamati adalah berat brangkasan segar, berat umbi serta umbi yang busuk. Setelah diperoleh data pengamatan, kemudian dilakukan analisis terhadap data tersebut dengan menggunakan uji $\mathrm{t}$ dengan taraf signifikan 5\% untuk mengetahui apakah terdapat perbedaan yang signifikan diantara 8 kombinasi

\section{HASIL}

Tabel 1 menunjukkan kombinasi FOT0N0 (kontrol) terlihat memiliki umbi yang busuk paling banyak yaitu 4 buah umbi.

Tabel 1. Hasil Analisis Data Tanaman Bawang Putih

\begin{tabular}{cccc}
\hline Perlakuan & Umbi Busuk (\%) & Berat Brangkasan (gram) & Berat Umbi (gram) \\
\hline F0T0N0 & $44,44 \%$ & 0,00368 & 0,00123 \\
\hline F0TON1 & $11,11 \%$ & 0,00879 & 0,00256 \\
\hline F0T1N0 & $33,33 \%$ & 0,00519 & 0,00216 \\
\hline F0T1NI & $33,33 \%$ & 0,00724 & 0,00245 \\
\hline F1T0N0 & $22,22 \%$ & 0,00991 & 0,00193 \\
\hline F1T0N1 & $44,44 \%$ & 0,00333 & 0,00111 \\
\hline F1T1N0 & $44,44 \%$ & 0,00532 & 0,00210 \\
\hline F1TINI & $22,22 \%$ & 0,00794 & 0,00243 \\
\hline
\end{tabular}




\section{PEMBAHASAN}

Pembusukan umbi bawang putih kebanyakan disebabkan oleh patogen tular tanah seperti Fusarium oxysporum. Ada beberapa faktor yang dapat menyebabkan pembusukan umbi, kemungkinan patogen terbawa bibit bawang putih yang terjadi karena sebelum proses penanaman tidak ada perlakuan terhadap bibit. Patogen juga dapat muncul dari media tanah yang digunakan untuk menanam umbi bawang putih. Dalam penelitian ini skema yang dilakukan dibuat alami seperti yang terjadi pada lahan pertanian, sehingga peneliti tidak melakukan sterilisasi pada media tanah. Hal ini memungkinkan adanya infeksi patogen yang berasal dari tanah.

Kondisi lingkungan di dalam tanah dapat mempengaruhi proses perkembangan mikroorganisme. Tingginya kapasitas penukar kation (KPK) memberikan medium tumbuh yang baik untuk Fusarium patogen. Kadar keasaman tanah juga memberikan pengaruh untuk peningkatan penyakit (Koike dkk, 2008), Bahkan menurut Hadiwiyono dan Widono (2008) nilai pH kurang dari 5,5 dapat meningkatkan intensitas penyakit lebih tinggi.

Dari tabel diatas diketahui bahwa kombinasi terbaik dalam menurunkan jumlah umbi busuk pada tanaman bawang putih adalah F0T0N1 dan F1TINI. Trichoderma merupakan cendawan tanah yang telah terbukti dapat digunakan sebagai pupuk hayati dan sudah dikomersilkan karena memang dapat meningkatkan hasil tanaman. Telah diketahui sejak lama bahwa $T$. harzianum ampu meningkatkan pertumbuhan dan perkembangan tanaman terutama terhadap pertumbuhan akar yang lebih banyak serta lebih kuat karena selain hidup di permukaan akar, koloninya dapat masuk ke lapisan epidermis akar (Howell 2004. Beberapa penelitian menunjukkan tanaman yang terdapat koloni T. harzianum pada permukaan akarnya hanya membutuhkan kurang dari $40 \%$ pupuk nitrogen dibandingkan dengan akar yang tanpa koloni (Harman 1998). Umbi busuk juga terlihat menurun intensitasnya pada F1T1N1. Pemberian Fusarium non-patogen dan Trichoderma secara bersamaan ternyata mampu menurutkan jumlah umbi busuk pada bawang putih. Hal ini menunjukkan bahwa Fusarium non-patogen mampu menghambat penyakit busuk pangkal pada bawang putih. Saat ini Fusarium non-patogen mulai digunakan sebagai mikroba antagonis pada patogen tular tanah (Dhingra et al., 2006). Menurut Horinouchi (2011), Fusarium nonpatogen tidak hanya mampu mengendalikan penyakit pada tanaman tetapi juga mampu memicu pertumbuhan tanaman. Sehingga kombinasi Trichoderma dan Fusarium nonpatogen merupakan perpaduan yang baik untuk mendukung pertumbuhan dan perkembangan tanaman.

Umbi bawang putih terbentuk dari gabungan beberapa suing dalam balutan yang kuat. Siung terbentuk di bagian bawah batang, yang sebenarnya siung ini merupakan bagian pengkal batang yang telah berubah bentuk dan fungsinya. Setiap umbi bawang putih mempunyai 3 sampai 36 siung bawang putih (Suriana, 2011). Siung bawang putih kalau dibelah menjadi dua di dalamnya terdapat lembaga dan lembaga ini akan menerobos pucuk siung Di samping lembaga, dalam suing bawang putih terdapat daging pembungkus lembaga, sekaligus menjadi gudang persediaan makanan yang dibutuhkan untuk pertumbuhan dan perkembangan tanaman baru (Santosa, 2000). Pada kombinasi perlakuan F0T0N1 dan F1T1N1 menunjukkan berat umbi yang besar. Besar dan beratnya umbi bawang putih disebabkan oleh banyaknya fotosintat yang ditimbun pada umbi.

Pada tabel 1 melalui analisis secara statistika pada taraf nyata $0,05 \%$ diperoleh $\mathrm{t}$ tabel 1,81 dan statistik t hitung sebesar 2.33 yang menunjukkan perbedaan berat segar tanaman yaitu pada perbandingan antara kombinasi tanpa Fusarium patogen, tanpa Trichoderma dan tanpa Fusarium non-patogen (F0T0N0) yang hanya sebesar 0.00368 gr dengan kombinasi perlakuan dengan Fusarium patogen (F1T0N0) yaitu sebesar 0,00991 gr. Hal ini dikarenakan jumlah umbi yang busuk pada kombinasi perlakuan FOT0N0 memiliki jumlah umbi busuk yang lebih banyak yaitu 44\% sedangkan kombinasi perlakuan F1T0N0 hanya 22\% umbi yang 
busuk. Umbi yang busuk akan mengganggu penyerapan unsur hara dan mineral sehingga aktivitas tanaman menjadi terhambat yang menjadikan pertumbuhan tanaman pun ikut terhambat terlihat dengan berat segar tanaman bawang putih yang lebih rendah (Kristiana, 2004). Kombinasi antara F0T0N1 (hanya dengan Fusarium non-patogen) yang memiliki umbi yang busuk berjumlah 1 sehingga berat segar tanaman menjadi cukup besar yakni 0.00879 gr Berbeda dengan kombinasi F1T0N1 yang memiliki umbi yang busuk berjumlah 4 sehingga berat segar tanaman lebih rendah yaitu hanya seberat $0.00333 \mathrm{gr}$.

\section{KESIMPULAN}

Berdasarkan hasil penelitian dapat diambil kesimpulan bahwa pemberian Fusarium non patogen pada tanaman bawang putih mampu menghambat penyakit busuk pangkal. Kombinasi antara Fusarium non-patogen dan Trichoderma dapat menghambat intensitas penyakit busuk pangkal dan meningkatkan pertumbuhan bawang putih.

\section{DAFTAR PUSTAKA}

Choiruddin MR. 2010. Virulensi dan Keanekaragaman Genetika Fusarium oxysporum f.sp.cepae Penyebab Busuk Pangkal Pada Bawang Putih [Skripsi] Surakarta (ID): Universitas Sebelas Maret.

Dhingra OD, Coelho-Netto RA, Rodrigues FA, Silva Jr GJ, Maia CB. 2006. Selection of Endemic Nonpathogenic Endophytic Fusarium oxysporum from bean rootand rhizospher competent xuorescent Pseudomonas species to suppress Fusarium-yellow of beans. Biol Control. vol 39: 75-86

Kristiana R. 2004. Integrasi pengendalian penyakit layu Fusarium pada bawang merah (Allium cepa var. ascalonicum) dengan binucleate rhizoctonia, dolomite dan kalium fosfat. [Skripsi]. Surakarta: Universitas Sebelas Maret.

Koike ST, Subharrau KV, Davis RM, Turini RA. 2008. Vegetable Disease Caused by Soilborne Pathogen. California: ANR Publication. pp. 8099.

Hadiwiyono dan Widono S. 2008. Hubungan Faktor Lingkungan Tanah Terhadap Intensitas Penyakit Busuk Pangkal Bawang Putih di Tawangmangu. Agrin. vol 2(1): 15-22.

Hadisoeganda WW, Suryaningsih dan Moekasan. 1995. Penyakit dan Hama Bawang Merah dalam Teknologi Produksi Bawang Merah. Jakarta: Badan Penelitian dan Pengembangan Pertanian. hal. 57-73.

Herlina L dan Pramesti D. 2004. Penggunaan kompos aktif Trichoderm harzianum dalam meningkatkan pertumbuhan tanaman cabai. Semarang: Fakultas Matematika dan Ilmu Pengetahuan Alam Universitas Negeri Semarang

Horinouchi H, Watanabe $\mathrm{H}$, Taguchi $\mathrm{Y}$, Muslim A, Hyakumachi M. 2011. Biological control of Fusarium wilt of tomato with Fusarium equiseti GF191 in both rockwool and soil systems. Bio Control. 56:915-923. DOI: http://dx.doi. org/10.1007/s10526-011-9369-3.

Rahayu S, Nadifah F, Prasetyaningsih Y. 2014. Jamur Kontaminan Pada Umbi Kentang. Biogenesis. vol 3(1): 28-32. Doi: https://doi.org/10.24252/bio.v3i1.563

Santoso HB. 2000. Bawang Putih. Edisi ke-12. Yogyakarta: Penerbit Kanisius.

Subowo, Sarmah, Khamdanah, Elsanti, Windiyati E. 2015. Status Sumberdaya Hayati Tanah pada Lahan Sawah Iintensif di Provinsi Jawa Barat dan Banten. Jurnal tanah dan iklim. 39(1): 33-40. http://dx.doi.org/10.2017/jti.v39i1.6218

Suriana N. 2011. Bawang Bawa Untung. Budi Daya Bawang Merah dan Bawang Putih. Yogyakarta: Cahaya Alam Pustaka. 